\title{
Two species of genus Carex sect. Spirostachyae (Cyperaceae) new to Bosnia and Herzegovina
}

\section{Dvije vrste roda Carex sect. Spirostachyae (Cyperaceae) nove za floru Bosne i Hercegovine}

Đorđije Milanovićl, ${ }^{*}$, Semir Maslo², Šemso Šarić3

\footnotetext{
I University of Banja Luka, Faculty of Forestry, Stepe Stepanovića 75A, 78000 Banja Luka, Bosnia and Herzegovina

2 Primary School, Lundåkerskola, Gislaved, Sweden

3 Jelaške, Olovo, Bosnia and Herzegovina
}

\begin{abstract}
During systematic field research of genus Carex in Bosnia and Herzegovina in the period of 2014-2018. two species from sect. Spirostachyae Drejer ex L. H. Bailey have been recorded for the first time in the flora of the country: Carex extensa Gooden. and Carex punctata Gaudin.While C. punctata is a quite common species growing in damp and wet habitat types over serpentine substrates in Central Bosnia, C. extensa is recorded as very rare along the Adriatic Sea coast on Klek Peninsula (southern Bosnia and Herzegovina), and recognized as critically endangered (CR) in the country.
\end{abstract}

Key words: Bosnia and Herzegovina, Carex extensa, Carex punctata, conservation status, new floristic records.

\section{INTRODUCTION - Uvod}

The genus Carex L. (Cyperaceae) is one of the most diverse and widely distributed angiosperm, especially in the temperate regions of the Northern Hemisphere (Reznicek, 1990). It consists of more than 2000 species, which are colonizing a great range of habitats (Frodin, 2004). Five subgenera (Carex, Kreczetoviczia, Psillophora, Vignea and Vigneastra) are recognized based on a comprehensive taxonomic account (Egorova, 1999). Section Spirostachyae Drejer ex L.H. Bailey belongs to the subge- nus Carex and mostly occurs in mesic places across Eurasia and N.Africa (Egorova, 1999). There are about 26 species of the section Spirostachyae occurring across Eurasia and N Africa, with 13 representatives distributed in Europe (Escudero et al., 2008). Of these species only three are distributed in the Balkan Peninsula: Carex distans L., Carex extensa Gooden. and Carex punctata Gaudin.

In the flora of Bosnia and Herzegovina (B\&H) the presence of 75 taxa of genus Carex at subspecies level have

* Corresponding author: Đorđije Milanović, University of Banja Luka, Faculty of Forestry, S. Stepanovića 75A, 78000 Banja Luka, Bosnia and 


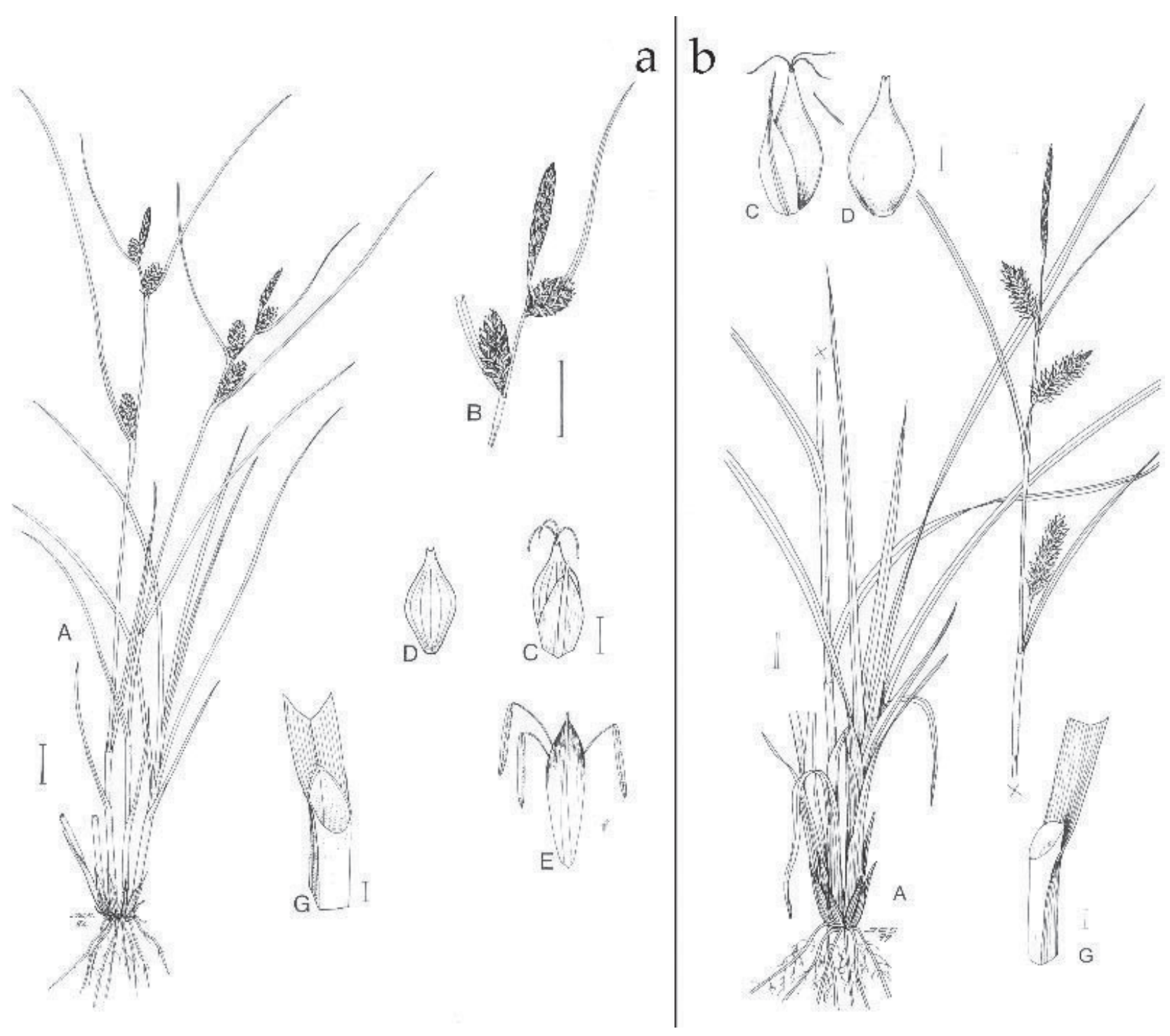

Figure I. (a) Carex extensa Gooden. and (b) Carex punctata Gaudin

A. habitus $B$. inflorescence $C$. female glume D. utricle E. male glume $G$. ligule

(Drawing from the book Danmarks halvgræsser, by Jens Christian Schou with permission of author)

Slika I. (a) Carex extensa Gooden. and (b) Carex punctata Gaudin

A. habitus B. cvast C. ženska pljeva D. mješak E. muška pljeva G. ligula

(Crtež iz knjige Danmarks halvgræsser, od Jens Christian Schou sa odobrenjem autora)

undoubtedly been recorded so far (Milanović, 2014a, 20I4b, 20I7). Only Carex distans L. was previously known from the section Spirostachyae (Beck-Mannagetta, 1903).

\section{MATERIAL AND METHODS - Materijal i metode}

The research area occupies the salt-sprayed coastal zone of Klek Peninsula in the extreme south of $\mathrm{BiH}$, and serpentine habitats of wider area of Central Bosnia as well. The specimens were collected and stored into the
Herbarium of the National Museum of Bosnia and Herzegovina (SARA) (voucher numbers: 5 I866, 5I867) and Herbarium of the Faculty of Forestry University of Banja Luka (voucher numbers: 22/0I-205, 22/0I-206, 22/0I-254). Identification was performed using the identification keys and descriptions provided by Chater (1980), Jermy et al. (2007) and Schou (2006). The nomenclature follows Jiménez-Mejías \& Luceño (20II). The distribution of target species is shown on the map using standard UTM grid $10 \times 10 \mathrm{~km}$. 


\section{RESULTS AND DISCUSSION - Rezultati i diskusija}

Carex extensa Gooden. and Carex punctata Gaudin belongs to Subgenus Carex, section Spirostachyae Drejer ex L. H. Bailey (Figure I). Generally, the main morphological characteristics of the section Spirostachyae are: primary rhizomes with short internodes, presence of leaf anteligule, lowest bract of the inflorescence leaf-like, sheathing, three stigmas, glabrous and smooth utricles, epidermal cells of utricles with red crystalloid bodies, bifid or bidentate utricle beak and ellipsoid achenes (Chater, 1980; Escudero \& Luceño, 2009).

In order to clarify the diagnostic characteristics of the target species within the section Spirostachyae, and its relation with morphologically similar section Ceratocystis Dumort. as well, the identification key is provided here, following Chater (1980) and Jermy et al. (2007):

I. The pistillate spikes generally ovoid or globose and approximate, on relatively short peduncles; achenes distinctly obovate. section Ceratocystis

I.The pistillate spikes short-cylindric, distant, the lower are often conspicuously pedunculate; achenes elliptic in outline. section Spirostachyae

2. Utricles indistinctly nerved. C. punctata

2. Utricles distinctly nerved ...3

3.The pistillate spikes far separated. Leaves of flowering stems flat, pure green. C. distans 3.The pistillate spikes usually clustered near stem apex. Leaves of flowering stems channelled or involute, glaucous to grayish green. C. extensa

\section{Carex punctata Gaudin I8I I, Agrost. Helv. 2: I52.}

C. punctata (synonym: Carex laevicaulis Seub., Fl. Azor.: 21. 1840) (Figure Ib) is a caespitose perennial with shortly creeping rhizomes. Culms are erect, 15-100 $\mathrm{cm}$ tall, trigonous. Leaves are $10-50 \mathrm{~cm} \times 2-5 \mathrm{~mm}$, usually as long as the stem, flat or shallowly keeled, pale or yellow-green. Ligule is $3 \mathrm{~mm}$ long, obtuse and tubular. Inflorescence is about $1 / 2$ length of stem. Bracts are leaf like, at least one usually but not invariably exceeding the inflorescence. Male spike I, 10-30 mm. Male glumes 3-4 mm, oblong-obovate, orange-brown; apex mucronate, often fimbriate. Female spikes 2-4, upper contiguous, lower distant, 5-25 mm, ovoid-cylindric. Female glumes 2.5-3.5 mm, obovate, yellowish or pale brown with green midrib, margin hyaline; apex acuminate or obtuse and mucronate. Utricles 3-4 mm, obovoid-ellipsoid, inflated, indistinctly nerved, shiny, pale green, often reddish-spotted, inserted at an angle of $75-80^{\circ}$ to the stem axis and therefore strongly patent, narrowing abruptly into a beak, widely bifid; stigmas 3
(Jermy et al., 2007). Chromosome numbers, $2 n=68$ (Escudero et al., 2008).

Recent floristic researches in the region of Balkan Peninsula show that this species has been overlooked in most of the neighbouring countries, probably due to morphological similarity to $C$. distans. Just in the last ten years it was first recorded in Montenegro (Stešević \& Drescher, 20I0), Croatia (Koopman \& Topić, 20II) and Albania (Barina et al., 20/3). Within the region $C$. punctata is registered also in Macedonia, Slovenia, Bulgaria and Greece (Maly, 1931-32; Chater, 1980; Martinčić, 2007).

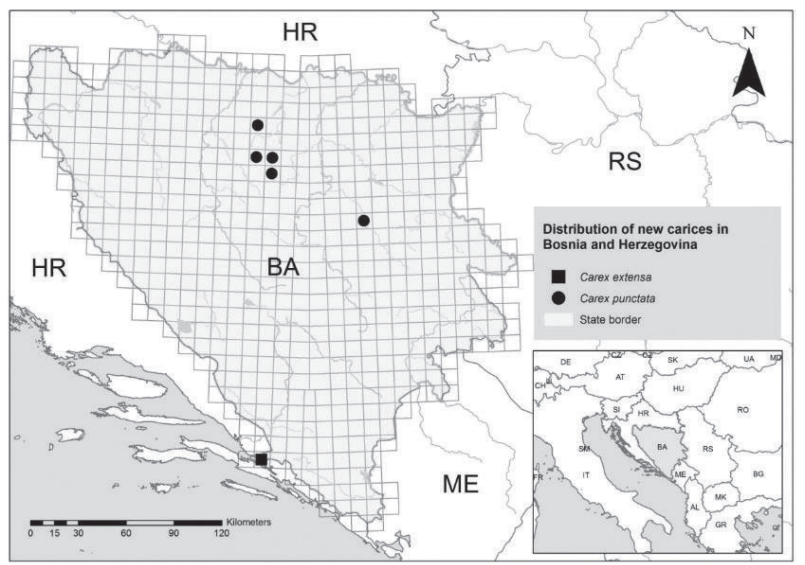

Figure 2. Distribution of Carex extensa and Carex punctata in Bosnia and Herzegovina

Slika 2. Rasprostranjenje vrsta Carex extensa i Carex punctata u Bosni i Hercegovini

The species is quite common in damp, grassy or rocky places near the sea in W. \& S. Europe, extending locally north-eastwards to S.W. Sweden, N. Poland and S.E. Austria (Chater, 1980). It is also known from sandy patches of marine marshes, sheltered rock ledges on sea-cliffs, and wetlands of siliceous substrates (Preston et al., 2002). Opposite to that, excluding only the record from Velika Ulcinjska beach (Stešević \& Drescher, 20I0), in the Western Balkans it occurs only in inland habitats, colonizing wet meadows, alkaline fens, degraded swamps, and wet road verges and ditches (Koopman \& Topić, 20I I; Kocjan, 20I4). In Bosnia and Herzegovina it has been recorded only over serpentine substrates in Central Bosnia (Figure 2). Here it grows in wet habitats alongside small serpentine watercourses and around water sources, in damp places on the edge of forests, and in ditches, wet verges and swards along macadam roads and skidding trails, where it occurs as quite common species in numerous populations. According to that, $C$. punctata probably occurs in the area more widely than the new records indicate. 
The researches of flora and vegetation of maritime marshes indicates that $C$. punctata and $C$. extensa often grow together. In addition to that, at all here stated finding places C. punctata grows together with similar $C$. distans. So, it can be overlooked with both similar species. But, the mature plants of $C$. punctata can be easily distinguished from both due to its light female glumes with green midrib and hyaline margin, as well as a bit smaller, shiny utricles, with indistinct nerves (Figure 3), particularly in fresh specimens. Contrary to $C$. distans, $C$. punctata has the lowest bract exceeding the inflorescence, which is flat, while in $C$. extensa this bract is involute (Figure $4 a-b$ ).

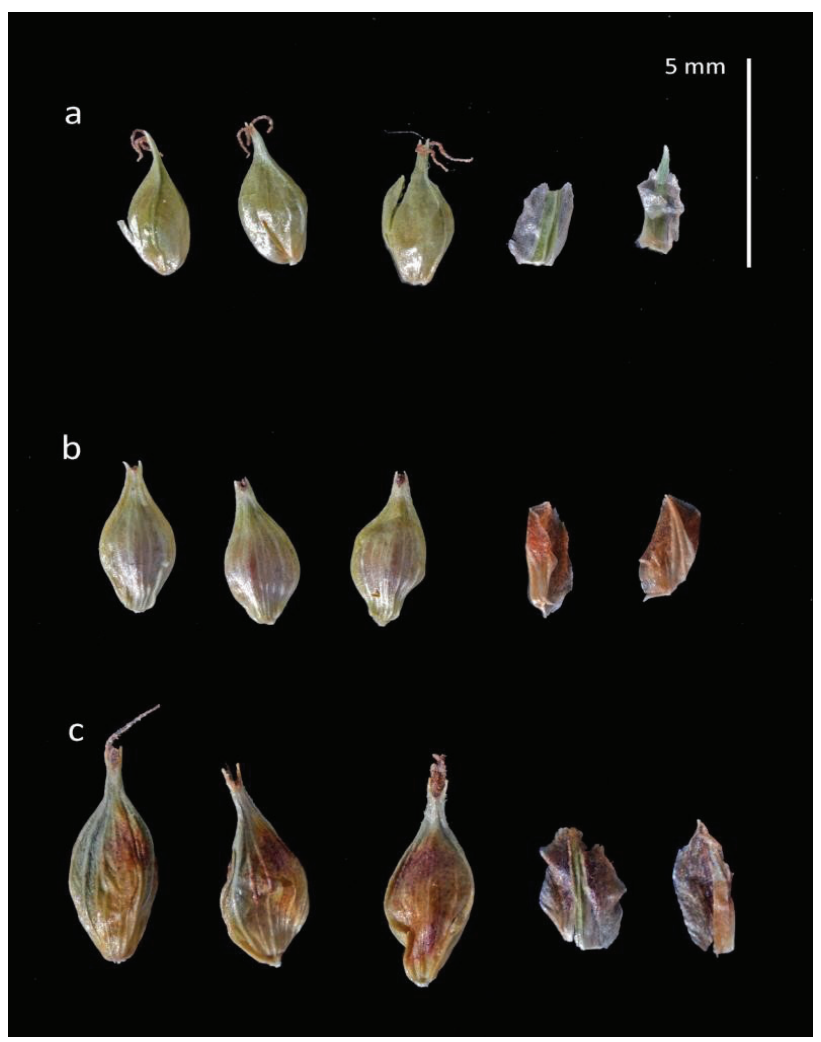

Figure 3. Utricles and female glumes of three similar species of the section Spirostachyae from Bosnia and Herzegovina:

(a) C. punctata, (b) C. extensa, (c) C. distans (@ Đ. Milanović)

Slika 3. Urtikule i ženske ljuske tri slične vrste sekcije Spirostachyae iz Bosne i Hercegovine: (a) C. punctata,

(b) C. extensa, (c) C. distans (@ Đ. Milanović)

\section{Carex extensa Gooden. I794, in Trans. Linn. Soc. London 2: I75.}

C. extensa (Figure Ia, $4 \mathrm{c}-\mathrm{d}$ ) is a densely tufted perennial with short rhizomes. Culms are erect, $5-45 \mathrm{~cm}$ tall, rigid and bluntly trigonous. Leaves are $5-35 \mathrm{~cm} \times 2-3 \mathrm{~mm}$, rigid, thick, keeled, often inrolled, grey-green or glaucous. Ligule $2 \mathrm{~mm}$, rounded. Inflorescence is about $1 / 3$ or $1 / 2$ length of stem. Bracts are leaf like, usually reflexed, far exceeding the inflorescence. Male spike usually I, rarely
2-3, 5-25 mm. Male glumes 3-4 mm, obovate-elliptic, redbrown, with paler midrib; apex obtuse. Female spikes 2-4, contiguous or lower sometimes distant, $5-20 \mathrm{~mm}$, subglobose to cylindric. Female glumes $1.5-2 \mathrm{~mm}$, broadly ovate, red-brown with pale midrib, margin hyaline; apex mucronate. Utricles 3-4 mm, ovoid or ellipsoid, weakly ribbed, grey-green or brownish with purplish blotches, beak smooth, notched; stigmas 3 (Jermy et al., 2007). Chromosome numbers, $2 \mathrm{n}=60$ (Escudero et al., 2008).

As opposed to $C$. punctata, $C$. extensa is a typical coastal sedge, occurs inland only along salt marshes (Preston et al., 2002). It grows along the European coast from the Baltic Sea via the Atlantic coast and the Mediterranean Basin to the Black Sea. It has been recorded in all Balkan countries which generally have coastal habitats: Montenegro, Albania, Bulgaria, Greece, Slovenia and Croatia (Rohlena, 1942; Chater, 1980; Martinčič, 2007; Nikolić, 2000).

As Bosnia and Hercegovina have only $24 \mathrm{~km}$ of the Adriatic sea shore and doesn't have salt marshes at all, the Klek Peninsula and the surrounding of the town of Neum are only potential finding places for the typical flora of maritime habitats. Although the flora and vegetation of Klek Peninsula were systematically investigated in the past (Kutleša \& Lakušić, 1964), C. extensa hasn't been recorded so far. During research of the flora of Klek Peninsula carried out in the period of October 2017-July 2018, the species was found as very rare, with less than 30 characteristic tufts, in a small bay under the locality of Izbroće in the southern part of the Peninsula, near an abandoned mussels farm. Considering that this species has a very restricted area of occupancy, and count very small numbers of adult plants (criteria D), it has to be included into the Red List of endangered plant species for Bosnia and Herzegovina, as critically endangered (CR) (IUCN, 200I).

\section{ACKNOWLEDGMENT - Zahvala}

This paper arose from two different projects conducted in the last two years:

- "The achievement of conservation of biodiversity through establishing and operative management of protected areas, and capacity building for Nature protection in Bosnia and Herzegovina", financed by UNEP (United Nations Environment Protection) and implemented by CENER 21 - Center for Energy, Environment and Resources, and

- "Study of endemic and threatened flora in NW Bosnia", financed by RUFFORD Foundation, and implemented by authors.

Authors would like to thank to all mentioned institutions and organizations for financial and logistic support during research, and for permission to use the data for this pa- 

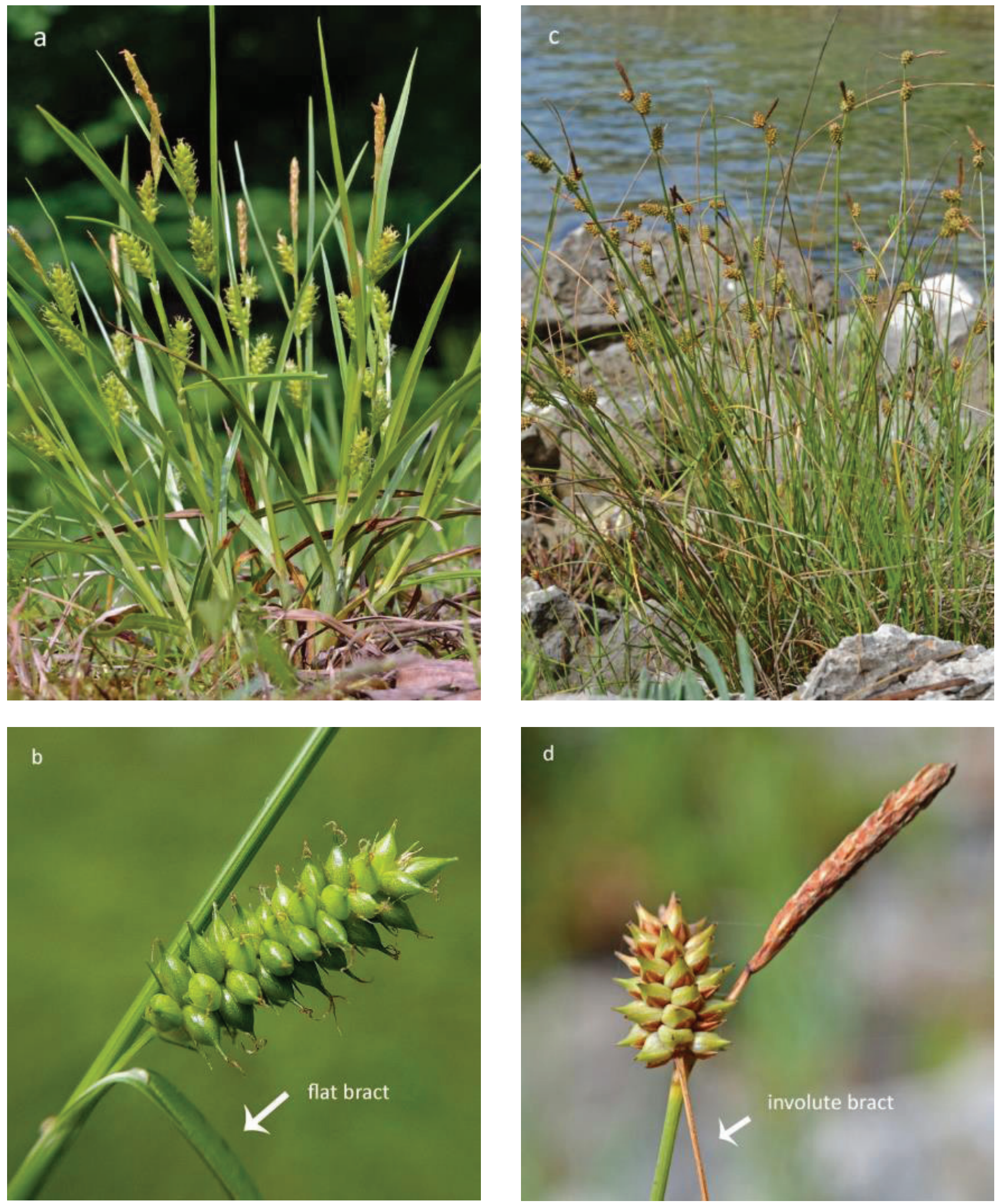

Figure 4. Carex punctata (a) habitus (b) female spike, and Carex extensa (c) habitus (d) female and male spike (C Đ. Milanović and Š. Šarić)

Slika 4. Carex punctata (a) habitus (b) ženski klas, i Carex extensa (c) habitus (d) ženski i muški klas (@ Đ. Milanović and Š. Šarić) 
per. Special thanks go to Nikša Čamo, Ivica Krmek, Maja Jaćimovska, Branislava Dukić,Vladimir Stupar and Jugoslav Brujić for the support during field research.

At the end, authors thank to Jens Christian Schou for his permission of the use of the species' drawing as well as Jessica Andersson for improving the English of this paper.

\section{REFERENCES - Literatura}

Barina, Z., Rakaj, M., \& Pifkó, D. (2013). Contributions to the flora of Albania 4. Willdenowia 43: I65-184.

Beck-Mannagetta, G. (1903). Flora Bosne, Hercegovine i novopazarskog Sandžaka I(I,2), Gymnospermae i Monocotyledones. Glasnik Zemaljskog muzeja u Bosni i Hercegovini I5(2): 185-230.

Chater, A.O. (1980). Carex. In:Tutin, T.G., Heywood,V.H., Burges, N.A., Moore, D.M.,Valentine, D.H.,Walters, S.M., Webb, D.A. (eds). Flora Europaea 5: 290-323. Cambridge: Cambridge University Press.

Egorova,T.V. (1999). Sedges (Carex L.) of Russian and Adjacent States within the limits of the Former USSR. St. Petersburg and St. Louis: Missouri Botanical Garden Press.

Escudero, M., \& Luceño M. (2009). Systematics and evolution of Carex sects. Spirostachyae and Elatae (Cyperaceae). Plant Systematics and Evolution 279: 163-189.

Escudero, M., Valcárcel,V., Vargas, P., \& Luceño, M. (2008). Evolution in Carex L. sect. Spirostachyae (Cyperaceae): a molecular and cytogenetic approach. Organisms, Diversity \& Evolution 7:27I-29I.

Frodin, D.G. (2004). History and concepts of big plant genera. Taxon 53(3): 753-776.

IUCN (200I). IUCN Red List Categories and Criteria:Version 3.I. IUCN Species Survival Commission. IUCN, Gland, Switzerland and Cambridge.

Jermy, A.C., Simpson, D.A., Foley, M.J.Y., \& Porter, M.S. (2007). Sedges of the British Isles. BSBI Handbook No I, 3rd edn. London: Botanical Society of the British Isles.

Jiménez-Mejías, P., \& Luceño, M. (20I I). Cyperaceae. In: Euro+Med Plantbase - the information resource for Euro-Mediterranean plant diversity.

Kocjan, J.M. (20I4). Prispevek k poznavanju razširjeosti nekaterih redkih, ogroženih ali drugače zanimivih taksonov v flori Slovenije - II. Hladnikia 33:3I-63.

Koopman, J., \& Topić, J. (20II). Carex punctata Gaudin (Cyperaceae), a new species in the Croatian flora. Natura Croatica 20( I): 225-228.

Kutleša, Lj., \& Lakušić, R. (1964). Flora i vegetacija poluotoka Kleka. Godišnjak Biološkog instituta Univerziteta u Sarajevu I7:6I-II5.

Maly, K. (193I-32). Carices der Balkanhalbinsel. Bulletin de l'institute et du jardin botaniques de l'université de Beograd 2(I-2): 59-66.

Martinčič, A. (2007). Carex L. In: Martinčič A.,Wraber T., Jogan N., Podobnik A.,Turk B.,Vieš B., Ravnik V., Frajman B., Strgulc Krajšek S., Trčak B., Bačič T., Fischer M.A., Eler K. \& Surina B., Mala flora Slovenije, ed. 4. Ljubljana:Tehniska zalozba Slovenije.

Milanović, Đ. (20I4a). Šaševi (Carex L.) Bosne i Hercegovine - taksonomska, morfološka i horološka studija. Diplomski rad. Banja Luka: Šumarski fakultet Univerziteta u Banjoj Luci.

Milanović, Đ. (20I4b). Prilog poznavanju rasprostranjenja nekih rijetkih vrsta iz roda Carex L. u Bosni i Hercegovini. Glasnik Sumarskog fakulteta Univerziteta u Banjoj Luci 22:5-2I. Milanović, Đ. (2017). Vaskularna flora akvatičnih i vlažnih staništa uz glacijalna jezera u Nacionalnom parku Sutjeska (Republika Srpska, Bosna i Hercegovina). Glasnik Šumarskog fakulteta Univerziteta u Banjoj Luci 26: 75-93.

Nikolić,T. (ed.) (2000). Flora Croatica, Index florae Croaticae Pars 3. Natura Croatica 9, Suppl. I: I-324.

Preston, C.D., Pearman, D.A., \& Dines, TD. (2002). New Atlas of the British and Irish Flora. Oxford: Oxford University Press.

Reznicek, A.A. (1990). Evolution in sedges (Carex, Cyperaceae). Canadian Journal of Botany 68: 1409-1432.

Rohlena, J. (1942). Conspectus florae montenegrinae. Preslia. Věstník (Časopis) československé botanické společnosti Prague 20-21: I-506.

Schou, J.C. (2006). Danmarks halvgræsser. Thisted: BFN's forlag.

Stešević, D., \& Drescher,A. (2010). Additions to the vascular flora of Montenegro (new taxa and new records). Natura Montenegrina 10(1): 7-16

\section{SAŽETAK}

Tokom sistematskog terenskog istraživanja roda Carex u Bosni i Hercegovini u periodu 20।4-2018. dvije vrste iz sekcije Spirostachyae Drejer ex L. H. Bailey prvi put su zabilježene u flori ove države: Carex extensa Gooden. i Carex punctata Gaudin. Rezultati ukazuju da je C. punctata prilično česta vrsta na vlažnim staništima na serpentinitima centralne Bosne, dok je C. extensa zabilježena $C$. extensa je zabilježena kao vrlo rijetka duž jadranske obale na poluotoku Kleku (južna Bosna i Hercegovina) i prepoznata kao kritično ugrožena vrsta (CR) u BiH. 